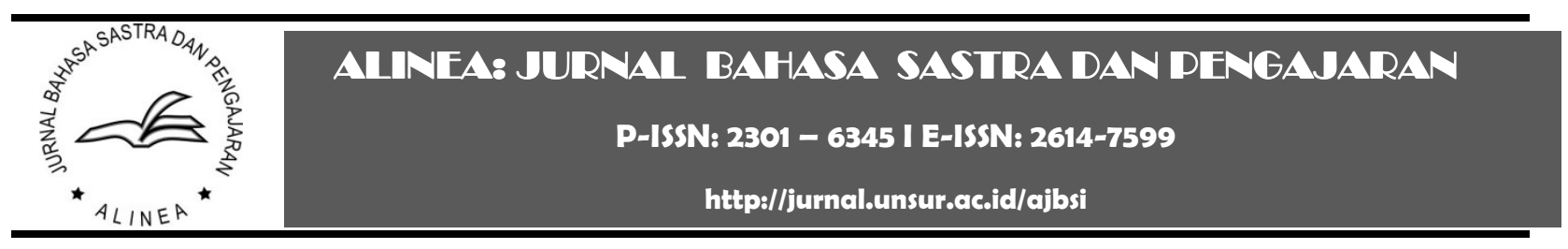

\title{
PENGGUNAAN MODEL PICTURE AND PICTURE DALAM PEMBELAJARAN MENULIS TEKS PROSEDUR
}

\author{
Yessy Handriani, Siti Maryam, D. Nurfajrin Ningsih \\ Universitas Suryakancana
}

Riwayat artikel:

Dikirim: 7 Mei 2020

Direvisi: 8 Agustus 2020

Diterima: 15 Agustus 2020

Diterbitkan: 30 Oktober 2020

Katakunci:

menulis, teks prosedur, picture and picture.

Keywords:

writing, procedural text, picture and picture

Alamat surat yessyhandriani3003@gmail.com

\begin{abstract}
Abstrak:
Artikel ini penggunaan model pembelajaran "Picture and Picture" dalam pembelajaran menulis teks prosedur. Metode yang digunakan ialah metode eksperimen dengan rancangan "one group pretest-posttest design". Sampel yang terpilih adalah kelas VII A SMP Terpadu Miftahul Ulum. Teknik pengumpulan data yang digunakan adalah penggunaan lembar tes, penggunaan lembar angket atau kuesioner, penggunaan pedoman observasi, dan penggunaan pedoman wawancara. Hasil penelitian ini menunjukkan 1) kemampuan menulis teks prosedur mengalami peningkatan dilihat dari perolehan nilai peserta didik dengan selisih 14 angka, 2) hasil uji prasyarat pengolahan data memperoleh nilai signifikansi sebesar 0,000 $<0,05$ sehingga dapat disimpulkan bahwa model membelajaran "Picture and Picture" dapat digunakan dalam pembelajaran teks prosedur, 3) model pembelajaran "Picture and Picture" dapat mempermudah pembelajaran menulis teks prosedur, dan 4) model pembelajaran "Picture and Picture" efektif digunakan dalam pembelajaran menulis teks prosedur.
\end{abstract}

\begin{abstract}
:
This article discusses the use the "Picture and Picture" learning model in learning to write procedural texts. The method used an experimental method with a "one group pretest-posttest design". The sample was class VII A SMP Terpadu Miftahul Ulum. The data collection techniques utilized test sheets, questionnaire sheets, observation guidelines, and interview guidelines. The results of this study indicate that 1) the ability to write procedural text has increased as seen from students' scores with 14 points increase 2) the results of the data processing of prerequisite test obtained a significance value of 0.000 $<0.05$ so it can be concluded that "Picture and Picture" learning model can be used in learning procedure text, 3) the "Picture and Picture" learning model can make it easier to learn to write procedure text, and 4) the "Picture and Picture" learning model is effective to use in learning to write procedure text.
\end{abstract}

\section{PENDAHULUAN}

Peningkatan kualitas pembelajaran merupakan salah satu pilar upaya peningkatan mutu pendidikan secara keseluruhan. Dalam pembelajaran bahasa terdapat keterampilan yang perlu dikuasai oleh peserta didik (Wulandari, Suryanto, \& Saddhono, 2015).

Selanjutnya, perlu dikemukakan bahwa keterampilan berbahasa dibagi menjadi dua, yaitu lisan dan tulis. Lisan meliputi menyimak dan berbicara, sedangkan keterampilan berbahasa tulis meliputi membaca dan menulis.

Dibandingkan dengan menyimak, berbicara, dan membaca, keterampilan menulis lebih sulit dikuasai bahkan oleh penutur asli bahasa yang bersangkutan sekalipun, hal ini disebabkan kemampuan menulis menghendaki penguasaan berbagai unsur kebahasaan dan unsur di luar bahasa itu sendiri yang akan menjadi isi tulisan (Iskandarwassid \& Sunendar, 2008). 
Menulis berarti proses menuangkan ide melalui tulisan, sehingga semakin banyak yang ditulis, berarti semakin banyak pula pemikiran yang tertuang dalam tulisan (Lestari, Dewi. W; Herdiantina; Sudrajat, 2018). Menulis merupakan suatu proses kegiatan untuk menghasilkan atau memproduksi dan untuk mengekspresikan, oleh karena itu, tujuan menulis untuk memberitahukan atau mengajar, meyakinkan atau mendesak, menghibur atau menyenangkan, dan mengutarakan/mengekspresikan perasaan dan emosi yang berapi-api (Tarigan, 2008).

Dalam kehidupan sehari-hari manusia sering mengerjakan dan melaksanakan sesuatu dengan dipandu oleh sebuah prosedur atau langkah-langkah secara tertulis agar aktivitas tersebut berjalan dengan baik. Ketentuan yang patut dituruti dalam membuat, menggunakan, dan melakukan sesuatu dalam pembelajaran disebut teks prosedur.

Lebih lanjut, (dalam (Kristiani, 2015) dijelaskan bahwa teks prosedur merupakan teks yang berisi langkah-langkah atau tahapantahapan yang perlu ditempuh untuk mencapai sebuah tujuan, sehingga penulisan teks prosedur yang baik akan memudahkan kita atau pembaca dalam melakukan apa yang tercantum di dalamnya.

Jadi, teks prosedur sendiri merupakan teks yang menunjang kita dalam kehidupan sehari-hari untuk melakukan aktivitas atau membuat sesuatu yang bermanfaat bagi kehidupan. Teks prosedur juga bertujuan untuk menjelaskan bagaimana sesuatu itu dibuat atau dilakukan dengan langkah-langkah yang urut (Priyatni, 2014).

Dalam teks prosedur diperlukan adanya penggunaan konjungsi dalam setiap langkahnya. Penggunaan konjungsi dalam teks prosedur dengan teks cerita lainnya berbeda. Apabila dalam teks cerita konjungsi itu digunakan untuk mengurutkan sebuah peristiwa yang dialami oleh tokoh utama, sedangkan dalam teks prosedur konjungsi dipergunakan untuk mengurutkan sebuah langkah/tahapan sesuai dengan tujuan (Mahsun, 2014).

Adapun struktur teks prosedur menurut (Harsiati, 2016) terdiri judul, pengantar yang menyatakan tujuan penulisan, bahan atau alat untuk melaksanakan suatu prosedur, dan langkah/tahapan dengan urutan yang benar, dapat berupa tahapan yang ditunjukan dengan sebuah penomoran, dapat ditunjukkan dengan kata yang menunjukkan urutan pertama, kedua, dsb, dan dapat berupa tahapan uang ditunjukkan dengan kata yang menunjukkan urutan waktu seperti sekarang, kemudian, setelah itu, dsb.

Pembelajaran menulis teks prosedur terdapat dalam kurikulum di kelas VII SMP . Jika diamati, kemampuan peserta didik di kelas terbilang rendah dalam memilih kata dan kalimat untuk menulis teks prosedur. Selain itu, beberapa kelemahan dalam menulis teks prosedur misalnya peserta didik sering keliru dalam mengurutkan urutan langkah-langkah teks prosedur secara tepat, kurangnya motivasi peserta didik dalam menulis, guru belum menerapkan metode dan media pembelajaran yang menarik, dan hasil tulisan peserta didik kurang variatif, karena peserta didik sering hanya mengingat apa yang telah diberitahukan oleh guru bukan dari hasil menemukan sendiri pengalaman itu.

Selain itu, guru umumnya belum menerapkan model pembelajaran yang menarik sehingga peserta didik kurang termotivasi dalam pembelajaran menulis teks prosedur. Berkaitan dengan permasalahan tersebut, artikel ini menawarkan salah satu alternatif dalam pembelajaran menulis teks prosedur yaitu dengan menggunakan model Picture and Picture.

Model.pembelajaran Picture and Picture menurut ialah suatu model belajar menggunakan gambar dan dipasangkan atau diurutkan menjadi urutan logis (Shoimin, 2016). Dengan penerapan model ini, diharapkan peserta didik dapat berperan aktif dan antusias dalam pembelajaran karena peserta didik dapat berkreasi sendiri dengan 
menggunakan media gambar sebagai penunjang penyusunan teks prosedur. Menurut (Muliawan, 2016) model picture and picture ini berprinsip dan memiliki cara kerja yang sama dengan metode pembelajaran menyusun sebuah gambar.

Penelitian mengeni penggunaan model Picture and Picture pernah dilakukan oleh (Fitriawati Musyafa, 2020) berjudul "Penggunaan Picture and Picture dalam Pembelajaran Menulis Cerpen". Hasil penelitian menunjukkan bahwa model pembelajaran picture and picture efektif dan dikategorikan dengan baik untuk meningkatkan kemampuan menulis cerita pendek. Hal itu, ditunjukkan oleh kemampuan peserta didik kelas eksperimen yang diberi (perlakuan) memiliki nilai lebih tinggi dengan nilai (posttest) 72,38, sedangkan kelas kontrol yang tidak diberikan (perlakuan) menghasilkan nilai (posttest) 64,43, dari hasil tes kelas memiliki nilai perbedaan 19,66. Dan jumlah jawaban kuesioner yang telah digunakan untuk peserta didik hampir $73 \%$ merasa bahwa model gambar difasilitasi pada penulisan, dan dianggap bahwa kegiatan menulis cerita pendek sangat menarik untuk dipelajari.

Penelitian lain dilakukan (Widyawati, 2019) berjudul "Keefektifan Model Pembelajaran Picture and Picture dalam Keterampilan Menulis Untuk Tingkat Universitas." Hasilnya, menunjukkkan model picture efektif dapat meningkatkan hasil tulisan teks recount mahasiswa semester 4 tingkat universitas. Subjek dalam penelitian ini adalah mahasiswa. sampel yang digunakan dalam penelitian ini adalah 60 mahasiswa yang dibagi menjadi 2 kelompok, 30 mahasiswa untuk kelas eksperiment dan 30 mhasiswa untuk kelas kontrol. Penelitian itu menggunakan buku dan tes sebagai sumber data. Test yang digunakan dalam penelitian adalah test menulis teks recount. Penelitian dilakukan menggunakan metode quantitatif yaitu ekperiment. Temuan dalam penelitian menunjukkan bahwa model pembelajaran picture and picture dapat meningkatkan hasil belajar. Nilai tertinggi adalah 92, nilai terendah adalah 56, dibandingkan mahasiswa yang tidak menggunakan model pembelajaran picture and picture. nilai rata -rata dan median kelas experiment yaitu 81,63 dan 77,5 . dan nilai rata-rata kemampuan menulis dikategorikan bagus. Sebaliknya, hasil dari test yang diterapkan kepada mahasiswa yang menggunakan teknik konvensuional atau kelas kontrol, menunjukkan bahwa nilai tertinggi dan terendah adalah 83 dan 50. nilai rata-rata dan median kelas kontrol yaitu 69,1 dan 70 . jika dikonsultasikan tingkatan nilai menulis, dikategorikan jelek atau kurang bagus.

Dengan demikian, dapat disimpulkan bahwa hasil penelitian menyatakan bahwa ada pengaruh yang bagus mengenai penggunaan model pembelajaran picture and picture dalam meningkatkan kemampuan menulis teks recount. Jadi, model pembelajaran picture and picture sangat efektif dalam meningkatkan kemampuan menulis.

Sejalan dengan kedua penelitian itu, dalam penelitian diterapkan model picture and picture pada pembelajaran. Yang berbeda dibandingkan dengan penelitian sebelumnya, yaitu penerapan pada pembelajaran menulis teks prosedur dengan tujuan, untuk mengetahui kemampuan peserta didik dalam pembelajaran menulis teks prosedur sebelum dan sesudah menggunakan model pembelajaran picture and picture pada peserta didik kelas VII SMP Terpadu Miftahul Ulum.

\section{METODE}

Metode yang digunakan dalam penelitian ini adalah quasi experiment atau eksperimen pura-pura. Arikunto dalam (Ningsih \& Firmansyah, 2018) menjekaskan bahwa eksperimen jenis ini belum memenuhi persyaratan seperti cara eksperimen yang dapat dikatakan ilmiah jika tidak mengikuti peraturan-peraturan tertentu salah satunya adalah dalam pengontrolan variabel.

Pelaksanaan penelitian ini memerlukan konsep dan variabel yang jelas serta peng- 
ukuran yang cermat, karena dalam penelitian ini diberikan suatu perlakuan untuk mengetahui pengaruh antara perlakuan dengan aspek tertentu yang akan diukur.Menurut (Sugiyono, 2008) "penelitian eksperimen dapat diartikan sebagai metode penelitian yang digunakan untuk mencari perlakukan tertentu terhadap yang lain dalam kondisi yang terkendalikan". Dalam penelitian eksperimen dibutuhkan sebuah perlakukan (treatment). Perlakuan yang digunakan ialah penggunaan model pembelajaran picture and picture.

Rancangan penelitian pre-ekspresimen yang digunakan adalah the one group pretestposttest design sehingga hanya ada satu kelompok saja tanpa ada kelompok kontrol. Rancangan ini dapat digambarkan sebagai berikut.

\section{\begin{tabular}{|l|l|}
\hline Pretes & Perlaku \\
Posttest
\end{tabular}}

Gambar 1. Rancangan the one group pretest posttest design

Dalam penelitian, populasi yang digunakan ialah salah satu tingkat atau kelas dari SMP Terpadu Miftahul Ulum. Populasi tersebut yakni kelas VII A dan VII B. Sampel yang terpilih untuk menerapkan model pembelajaran picture and picture ialah kelas VII A dengan jumlah peserta didik sebanyak 28 peserta didik. Adapun teknik pengambilan sampel menggunakan teknik random sampling atau sampel acak sehingga sampel dipilih melalui proses pengocokan populasi.

Instrumen yang digunakan berupa lembar tes, lembar angket atau kuesioner, pedoman observasi, dan pedoman wawancara. Lembar tes yang digunakan dalam artikel ini adalah lembar teks yang berisi tugas untuk menulis teks prosedur sebelum dan sesudah penerapan model pembelajaran picture and picture. Lembar angket yang digunakan adalah angket tertutup yang jawabannya sudah disediakan oleh penulis dengan menggunakan model skala Guttman yang berisi 10 butir pertanyaan.
Wawancara yang digunakan dalam penelitian ini ialah dengan mengajukan beberapa pertanyaan langsung kepada guru bahasa Indonesia kelas VII seputar kemampuan menulis teks prosedur peserta didik sebelum dan sesudah diterapkannya model pembelajaran picture and picture.

Observasi yang digunakan dalam penelitian ini adalah dengan mengamati proses pembelajaran menulis teks prosedur yang menerapkan model pembelajaran picture and picture untuk dapat melihat keaktifan peserta didik dalam pembelajaran teks prosedur.

Data yang telah didapatkan dianalisis dengan memberikan nilai pada hasil prates dan postes untuk mengetahui kemampuan menulis teks prosedur peserta didik dengan memperhatikan struktur teks prosedur, urutan langkah-langkahnya, dan penggunaan aspek kebahasaan sebagai acuan untuk penilaian dengan pedoman sebagai berikut.

\section{Tabel 1. Format Penilaian Menulis Teks Prosedur}

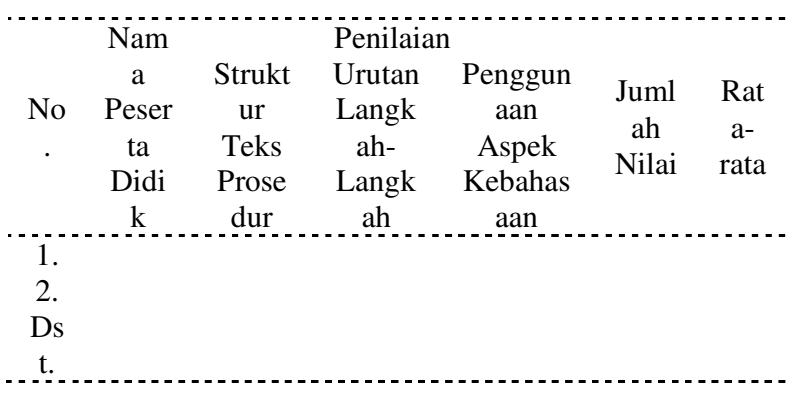

Dengan skala penilaian untuk setiap aspek, di antaranya:

0-60 : Tidak sesuai

61-80 : Sesuai

81-100 : Sangat sesuai

Nilai dari setiap aspek dijumlahkan secara keseluruhan lalu dihitung rataratanya. Cara mencari rata-rata, sebagai berikut.

$\frac{\text { Jumlah Nilai }}{3}=$ Nilai rata-rata 
Untuk mengolah hasil angket peserta didik dapat disimpulkan bahwa apabila hasil jawaban responden banyak memilih "ya" berarti penerapan model pembelajaran picture and picture dalam pembelajaran menulis teks prosedur dapat dikatakan efektif. Sedangkan apabila hasil jawaban responden banyak memilih "tidak" berarti penerapan model pembelajaran picture and picture dalam pembelajaran teks prosedur tidak efektif. Untuk mengolah hasil observasi dan hasil wawancara dapat disimpulkan dari data yang didapatkan.

Adapun pengolahan data secara kuantitatif dalam penelitian ini menggunakan program software SPSS versi 24 dengan prosedur pengujian statistik yang akan dilakukan adalah :

Uji persyaratan pengolahan data

\section{a. Menguji normalitas data}

Pengujian ini dilakukan untuk mengetahui apakah hasil dari masing-masing sampel berdistribusi normal atau tidak. Hasil uji normalitas masing-masing kelompok sampel dilakukan dengan uji Shapiro-wilk karena jumlah sampel $<50$ dengan taraf signifikansi 0,05 . Kriteria pengujian adalah $\mathrm{H}_{0}$ diterima, apabila nilai signifikansi $>0,05$ dan $\mathrm{H}_{0}$ ditolak jika nilai signifikansi $<0,05$.

\section{b. Uji Hipotesis}

Pengujian ini dilakukan untuk mengetahui apakah hipotesis yang diberikan dapat diterima atau ditolak dengan menghitung nilai $\mathrm{t}$ dan membanding nilai $\mathrm{t}$ hitung dan $\mathrm{t}$ tabel dengan mengaplikasikan pilihan paired sampel $T$ test dalam software SPSS 24. Dengan cara ini dapat melihat apakah terdapat perbedaan hasil menulis teks prosedur peserta didik sebelum dan sesudah menerapkan model pembelajaran picture and picture.

\section{HASIL PENELITIAN}

Penelitian ini dilaksanakan di SMP Terpadu Miftahul Ulum. Kegiatan pembelajaran berlangsung di kelas VII A. Pembelajaran dalam menulis teks prosedur menggunakan model pembelajaran picture and picture dimulai dengan guru menyampaikan kompetensi yang ingin dicapai atau tujuan pembelajaran serta menyampaikan motivasi sebelum dimulainya pembelajaran. Pada kegiatan ini peserta didik hanya mendengarkan apa yang disampaikan oleh guru.

Selanjutnya, guru menjelaskan materi pembelajaran menulis teks prosedur dan memperkenalkan gambar-gambar yang berkenaan dengan materi. Peserta didik dapat secara bergantian mengurutkan gambar-gambar yang telah disediakan menjadi suatu urutan yang logis dan memaparkan alasan atau dasar pemikirannya dari penempatan gambar tersebut. Setelah itu, peserta didik dibagi menjadi beberapa kelompok untuk berdiskusi mengenai teks prosedur yang akan dibuat. Pada akhir pembelajaran peserta didik mengumpulkan hasil penulisan teks prosedur membuat makanan daerah.

\section{Kemampuan Menulis Teks Prosedur}

Kemampuan awal (prates) peserta didik sebelum pemberian perlakuan berupa penerapan model pembelajaran picture and picture nilai rata-rata sebesar 68,61 , nilai terendah sebesar 60, dan nilai tertinggi sebesar 79 dengan sampel sebanyak 28 peserta didik.

Adapun data hasil tes setelah diberikan perlakuan dalam pembelajaran menulis teks prosedur membuat makanan daerah dengan menggunakan model pembelajaran picture and picture nilai rata-rata sebesar 82,36 , nilai terendah sebesar 75, dan nilai tertinggi sebesar 90.

Berdasarkan perhitungan dapat disimpulkan bahwa terdapat perbedaan yang cukup signifikan dari nilai prates dan postes yang memiliki selisih nilai rata-rata sebesar 14 . 
Untuk lebih jelasnya lagi dapat dilihat dari tabel berikut ini.

Tabel 2. Hasil Perhitungan Statistik Deskriptif Prates dan Postes

\begin{tabular}{|c|c|c|c|c|c|}
\hline \multicolumn{6}{|c|}{ Descriptive Statistics } \\
\hline & $\mathrm{N}$ & $\underset{\text { umim }}{\operatorname{Minim}}$ & $\begin{array}{c}\text { Maxim } \\
\text { um }\end{array}$ & $\begin{array}{l}M e \\
\text { an }\end{array}$ & $\begin{array}{c}\text { Std. } \\
\text { Deviation }\end{array}$ \\
\hline Prates & $\begin{array}{l}2 \\
8\end{array}$ & 60 & 79 & $\begin{array}{r}68 \\
61\end{array}$ & $6,094^{-}$ \\
\hline
\end{tabular}

Dalam tabel, dapat dilihat bahwa kedua nilai memiliki perbedaan. Kedua nilai tersebut memiliki rata-rata yang berbeda yakni nilai rata-rata prates sebesar 68,61 sedangkan nilai rata-rata postes sebesar 82,36 . Nilai prates dan postes tersebut memiliki perbedaan dengan selisih sebesar 14. Dengan sd postes lebih kecil dari prates yang artinya skor nilai peserta didik dalam postes tidak bervariatif jika dibandingkan dengan skor nilai pada prates. Nilai tertinggi dalam postes mengalami peningkatan dari hasil prates sebelumnya dari 79 menjadi 90. Begitu pun dengan nilai terkecil hasil postes mengalami peningkatan dari 60 menjadi 75 .

Dengan demikian, dapat disimpulkan bahwa kemampuan peserta didik setelah diterapkannya model pembelajaran picture and picture lebih baik daripada kemampuan awal peserta didik sebelum diterapkannya model pembelajaran picture and picture.

Untuk mengetahui efektivitas penggunaan model pembelajaran picture and picture dapat diuji menggunakan uji parametrik paired sampel $t$ test dengan menggunakan software SPSS 24 dengan terlebih dahulu dilakukan uji normalitas distribusi populasi.

\section{1) Uji Normalitas}

Setelah mengetahui nilai rata-rata dari setiap variabel dilanjutkan dengan menguji normalitas data. Dalam pengujian ini, peneliti menggunakan uji shapiro-Willk karena sampel $<50$ dengan taraf signifikansi 0,05. Kriteria pengujiannya adalah $\mathrm{H}_{0}$ diterima jika nilai signifikansi $>0,05$ dan $\mathrm{H}_{0}$ ditolak jika nilai signifikansi $<0,05$. Adapun hipotesis yang digunakan ialah sebagai berikut.

\section{$\mathrm{H}_{0}$ : Data berasal dari populasi yang berdistribusi normal \\ $\mathrm{H}_{1}$ : Data berasal dari populasi yang tidak berdistribusi normal}

Untuk melihat hasil perhitungan uji normalitas data yang lebih jelas dapat dilihat dari tabel berikut ini.

Tabel 3. Uji Normalitas Data Prates dan Postes

Tests of Normality

\begin{tabular}{|c|c|c|c|c|c|c|}
\hline & \multicolumn{3}{|c|}{ Kolmogorov-Smirnov a } & \multicolumn{3}{|c|}{ Shapiro-Wilk } \\
\hline & Statistic & $\mathrm{df}$ & Sig. & Statistic & df & Sig. \\
\hline Prates & 0,152 & 28 & $\begin{array}{r}0,09 \\
8\end{array}$ & 0,930 & 28 & 0,061 \\
\hline Postes & 0,216 & 28 & 0,00 & 0,936 & 28 & 0,087 \\
\hline
\end{tabular}

Berdasarkan tabel di atas, diperoleh hasil uji normalitas data dilihat dari uji shapirowillk untuk kemampuan menulis teks prosedur membuat makanan daerah sebelum dan sesudah diterapkannya model pembelajaran picture and picture dapat disimpulkan bahwa kedua data tersebut berdistribusi normal. Hal ini berdasarkan pada hasil uji normalitas yaitu hasil prates memperoleh nilai signifikansi sebesar 0,061 dan hasil postes memperoleh nilai signifikansi sebesar 0,087 . Kedua nilai signifikansi tersebut menunjukkan bahwa nilai $>$ taraf signifikansi 0,05 , sehingga $\mathrm{H}_{0}$ diterima dan dapat disimpulkan bahwa data berasal dari populasi yang berdistribusi normal. Karena kedua data tersebut berdistribusi normal maka pengolahan data dilanjutkan dengan uji parametrik paired sampel t test.

\section{2) Uji Paired Sampel T Test}

Untuk mengetahui penggunaan Model Pembelajaran Picture and Picture dapat diuji menggunakan uji parametrik paired sampel $t$ test dengan menggunakan software SPSS 24. Taraf signifikansi yang digunakan adalah 0,05, dengan kriteria pengujian $\mathrm{H}_{0}$ diterima jika nilai 
signifikansi $>0,05$ dan $\mathrm{H}_{0}$ ditolak jika nilai signifikansi $<0,05$. Adapun hipotesis yang digunakan adalah sebagai berikut.

\section{$\mathrm{H}_{0}$ : Model Pembelajaran Picture and Picture tidak dapat digunakan dalam pembelajaran menulis teks prosedur. \\ $\mathrm{H}_{1}$ : Model Pembelajaran Picture and Picture dapat digunakan dalam pembelajaran menulis teks prosedur.}

Dari hasil uji paired sampel t test pada dapat disimpulkan bahwa model pembelajaran picture and picture dapat digunakan dalam pembelajaran menulis teks prosedur karena memperoleh nilai signifikansi sebesar $0,000<$ 0,05 sehingga $\mathrm{H}_{0}$ ditolak. Jadi, kesimpulannya bahwa "model pembelajaran picture and picture dapat digunakan dalam pembelajaran menulis teks prosedur".

Oleh karena itu penelitian ini meperkuat beberapa penelitian sebelumnya. Bahwa model picture and picture dapat meningkatkan pembelajaran menulis teks recount, cerpen, dan teks prosedur. Hal tersebut sejalan dengan pernyataan (Lubis, 2017) bahwa model pembelajaran picture and picture ini dapat digunakan dalam berbagai mata pelajaran dan tentunya dengan kemasan dan kreatifitas guru.

Adapun hasil dari pengolahan data, peserta didik pun mengalami peningkatan dari perolehan nilai prates dan postes. Peningkatan tersebut dapat dilihat dari perbedaan nilai ratarata yang diperoleh. Untuk lebih jelasnya lagi dapat dilihat pada grafik berikut.

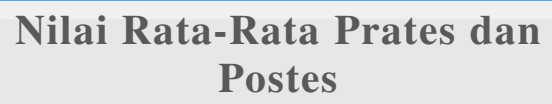

100

50

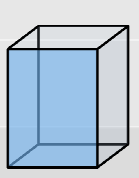

0

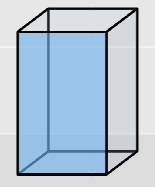

Nilai Prates Nilai Postes
Grafik di atas menjelaskan bahwa bahwa ada peningkatan perolehan nilai rata-rata prates dan postes. Nilai rata-rata prates adalah 68 sedangkan nilai rata-rata postes adalah 82 . Sehingga diperoleh selisih 14 angka dalam penilaian tersebut. Adapun hasil dari pengujian hipotesis yang diperoleh, ternyata $\mathrm{H}_{0}$ yang diajukan peneliti ditolak. Dengan begitu, hipotesis $\mathrm{H}_{1}$ diterima dengan pernyataan bahwa model pembelajaran picture and picture dapat digunakan dalam pembelajaran menulis teks prosedur. sehingga dapat disimpulkan bahwa "model pembelajaran picture and picture dapat digunakan dalam pembelajaran menulis teks prosedur peserta didik kelas VII SMP Terpadu Miftahul Ulum."

Berdasarkan hasil observasi penggunaan model pembelajaran picture and picture juga memperoleh hasil bahwa peserta didik dapat merespon salam dan menjawab pertanyaan yang berkaitan dengan materi sebelumnya dengan materi yang akan dipelajari yang diajukan oleh peneliti, peserta didik pun menyimak setiap materi yang disampaikan oleh peneliti.

Dengan menggunakan model pembelajaran ini peserta didik terlihat lebih percaya diri dan aktif dalam pembelajaran menulis teks prosedur. Peserta didik pun mampu menyusun teks prosedur dengan memperhatikan struktur dan unsur kebahasaannya. Peserta didik mampu menyampaikan hasil diskusinya di depan kelas dan dapat menentukan kesalahan yang dilakukan oleh peserta didik.

Penggunaan model picture and picture ini membuat peserta didik lebih aktif dalam pembelajaran di kelas, karena sebelum penggunaan model atau prates peserta didik cenderung ada yang aktif dan ada yang berdiam diri saja.

Dari hasil analisis angket menunjukkan bahwa model pembelajaran picture and picture dapat mempermudah pembelajaran menulis teks prosedur. Dengan menggunakan model tersebut dapat mendorong peserta didik 
dalam menemukan ide dengan persentase $100 \%$.

Hasil wawancara dengan guru bahasa Indonesia pun menunjukkan bahwa model pembelajaran picture and picture dapat digunakan dalam pembelajaran menulis teks prosedur. Menurut guru, sebelum diterapkannya model pembelajaran peserta didik cenderung ada yang aktif dan ada yang pasif tetapi ketika sudah diterapkannya model pembelajaran tersebut membuat peserta didik lebih aktif dalam pembelajaran dengan adanya pembagian tugas antara yang menulis teks prosedur dan ada yang mengurutkan gambar mengenai langkah-langkahnya.

\section{SIMPULAN}

Kemampuan menulis teks prosedur mengalami peningkatan dilihat dari nilai yang diperoleh peserta didik. Pada pelaksanaan prates menghasilkan nilai rata-rata sebesar 68,61 dengan nilai tertinggi 79 dan nilai terendah 60. Sedangkan hasil pelaksanaan postes menghasilkan nilai rata-rata sebesar 82,36 dengan nilai tertinggi 90 dan nilai terendah 75. Dengan begitu nilai postes ini mengalami peningkatan dengan selisih nilai rata-rata prates dan postes sebesar 14 .
Hasil uji parametrik paired sample $t$ test, memperoleh nilai signifikansi sebesar $0,000<0,05$ sehingga $\mathrm{H}_{0}$ ditolak. Jadi, dapat disimpulkan bahwa Model Pembelajaran Picture and Picture dapat digunakan dalam pembelajaran menulis teks prosedur. Dengan demikian, hipotesis yang diajukan dalam penelitian ini "model pembelajaran picture and picture dapat digunakan dalam pembelajaran menulis teks prosedur" dapat diterima, karena dengan penggunaan model pembelajaran picture and picture dalam pembelajaran menulis teks prosedur ternyata dapat meningkatkan kemampuan belajar peserta didik.

Hasil analisis angket menunjukkan bahwa model pembelajaran picture and picture dapat mempermudah pembelajaran menulis teks prosedur karena dengan menggunakan model tersebut dapat mendorong peserta didik dalam menemukan ide dengan persentase $100 \%$. Hasil wawancara dengan guru bahasa Indonesia pun menunjukkan bahwa model pembelajaran picture and picture dapat digunakan dalam pembelajaran menulis teks prosedur.

\section{DAFTAR PUSTAKA}

Fitriawati Musyafa, N. (2020). Penggunaan Model Picture and Picture dalam Pembelajaran Menulis Cerpen. Alinea: Jurnal Bahasa, Sastra, dan Pengajaran, 9(1), 37. https://doi.org/10.35194/alinea.v9i1.626

Harsiati, T. dkk. (2016). Bahasa Indonesia SMP/MTS Kelas VII. Jakarta: Kemendikbud.

Iskandarwassid, \& Sunendar, D. (2008). Strategi Pembelajaran Bahasa. Bandung: Rosdakarya.

Kristiani, W. K. dkk. (2015). Penerapan Metode Demonstrasi Guru Bahasa Indonesia dalam Pembelajaran Teks Prosedur Pada Siswa Kelas VIII A1 SMP Negeri 3 Sawan. E-Jurnal Jurusan Pendidikan Bahasa dan Sastra Indonesia., 3(1).

Lestari, Dewi. W; Herdiantina; Sudrajat, R. T. (2018). Pembelajaran Menulis Teks Prosedur Dengan Menggunakan Metode Ctl (Contextual Teaching and Learning ) Pada Siswa Kelas X Man Cimahi. Parole: Jurnal Pendidikan Bahasa dan Satra Indonesia. 
Lubis, R. R. (2017). Model Pembelajaran Picture and Picture untuk Meningkatkan Hasil Belajar Siswa. Prosiding Seminar Nasional Tahunan Fakultas Ilmu Sosial Universitas Negeri Medan.

Mahsun. (2014). Teks dalam Pembelajaran Bahasa Indonesia Kurikulum 2013. Jakarta: Rajawali Press.

Muliawan, J. U. (2016). Model Pembelajaran Spektakuler. Yogyakarta: Ar-Ruzz Media.

Ningsih, D. N., \& Firmansyah, A. F. (2018). Keefektifan Metode Sugestopedia Untuk Meningkatkan Kemampuan Menulis Teks Drama. Connect. Cianjur: Unsur Press.

Priyatni, E. T. (2014). Desain Pembelajaran Bahasa Indonesia dalam Kurikulum 2013. Malang: Bumi Karsa.

Shoimin, A. (2016). 68 Model Pembelajaran Inovatif dalam Kurikulum 2013. Yogyakarta: ArRuzz Media.

Sugiyono. (2008). Metode Penelitian Pendidikan Pendekatan Kuantitatif, Kualitatif, dan R\&D. Bandung: Alfabeta.

Tarigan, H. G. (2008). Menulis sebagai Suatu Keterampilan Berbahasa. Berkeley: Angkasa.

Widyawati, W. Y. (2019). Keefektifan Model Pembelajaran Picture and Picture dalam Keterampilan Menulis untuk Tingkat Universitas. KREDO : Jurnal Ilmiah Bahasa dan Sastra. https://doi.org/10.24176/kredo.v2i2.3027

Wulandari, Y., Suryanto, E., \& Saddhono, K. (2015). Penerapan Metode Picture and Picture untuk Meningkatkan Motivasi dan Keterampilan Menulis Teks Narasi pada Siswa Sekolah Menengah Kejuruan. Paedagogia. 